Prepared in cooperation with the California Department of Water Resources

\title{
Water Temperature Differences by Plant Community and Location in Re-established Wetlands in the Sacramento- San Joaquin Delta, California, July 2005 to February 2008
}

Data Series 882

U.S. Department of the Interior

U.S. Geological Survey 
Cover. Photo showing west side of 55-centimeter deep wetland on Twitchell Island, California. Photo by Robin L. Miller. 


\section{Water Temperature Differences by Plant Community and Location in Re-established Wetlands in the Sacramento-San Joaquin Delta, California, July 2005 to February 2008}

By Kathryn L. Crepeau and Robin L. Miller

Prepared in cooperation with the California Department of Water Resources

Data Series 882 


\title{
U.S. Department of the Interior SALLY JEWELL, Secretary
}

\section{U.S. Geological Survey Suzette M. Kimball, Acting Director}

\author{
U.S. Geological Survey, Reston, Virginia: 2015
}

For more information on the USGS - the Federal source for science about the Earth, its natural and living resources, natural hazards, and the environment, visit http://www.usgs.gov or call 1-888-ASK-USGS.

For an overview of USGS information products, including maps, imagery, and publications, visit http://www.usgs.gov/ pubprod

To order this and other USGS information products, visit http://store.usgs.gov

Any use of trade, firm, or product names is for descriptive purposes only and does not imply endorsement by the U.S. Government.

Although this information product, for the most part, is in the public domain, it also may contain copyrighted materials as noted in the text. Permission to reproduce copyrighted items must be secured from the copyright owner.

Suggested citation:

Crepeau, K.L., and Miller, R.L., 2014, Water temperature differences by plant community and location in re-established wetlands in the Sacramento-San Joaquin Delta, California, July 2005 to February 2008: U.S. Geological Survey Data Series 882, 20 p., http://dx.doi.org/10.3133/ds882.

ISSN 2327-638X (online) 


\section{Contents}

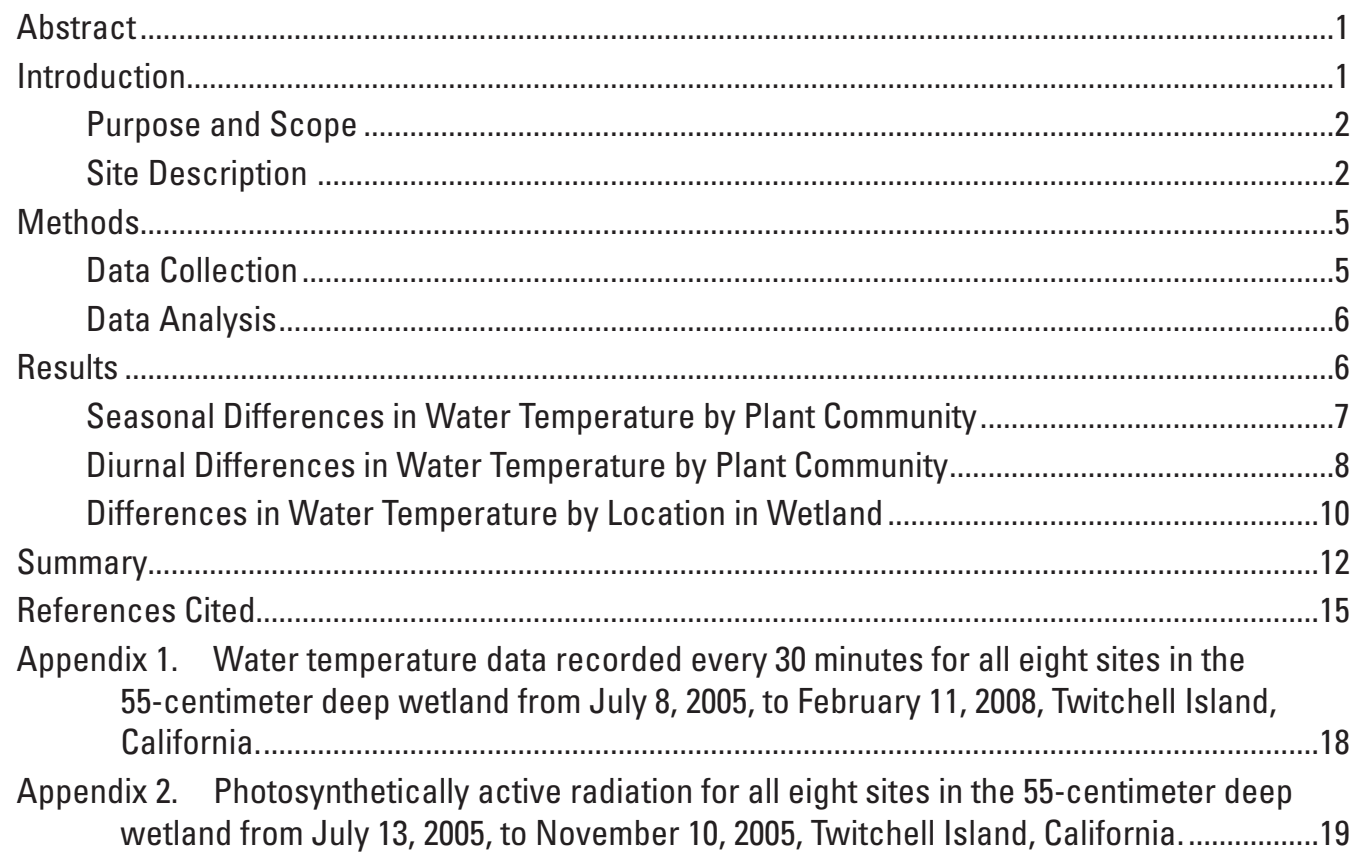




\section{Figures}

1. Map showing the location of Twitchell Island in the Sacramento-San Joaquin River Delta of California

2. Aerial photo of 55-centimeter deep wetland on Twitchell Island, California, showing the locations of water-temperature sensors.

3. Diagram showing placement of temperature sensors in the water column

4. Photo showing areas of emergent and submerged and floating vegetation in the 55-centimeter deep wetland...

5. Graphs showing mean water temperatures in areas of emergent and submerged vegetation at different times of year, Twitchell Island, California: $A$, August 24-28, 2005; B, December 8-12, 2005; and C, March 10-14, 2007

6. Graphs showing water temperature recorded during August 24-28, 2005, Twitchell Island, California, for sites near the inflow compared to water temperature for sites in the interior in areas of $A$, emergent vegetation; and $B$, submerged vegetation

\section{Tables}

1. Site number, site identification, sensor location, sensor depth, and measured photosynthetically active radiation in the 55-centimeter deep wetland, Twitchell Island, California

2. Summary of water temperature data at three depths for submerged vegetation compared to emergent vegetation, Twitchell Island, California, July 2005 to February 2008

3. Summary of water temperature data at three depths, by season, for submerged vegetation compared to emergent vegetation, Twitchell Island, California, July 2005 to February 2008

4. Summary of water-temperature by depth and season, at 3 a.m. and 3 p.m., for areas of submerged and emergent vegetation, Twitchell Island, California, July 2005 to February 2008

5. Summary of water temperatures for sites near the inflow and sites in the wetland interior in areas of submerged vegetation and emergent vegetation, Twitchell Island, California, July 2005 through December 2006

1-1. Water temperature data recorded every 30 minutes for all eight sites in the 55-centimeter-deep wetland from July 8, 2005, to February 11, 2008, Twitchell Island, California (Provided separately as a downloadable Microsoft Excelß file.)

2-1. Photosynthethically active radiation for all eight sites in the 55-centimeter deep wetland from July 13, 2005 to November 10, 2005, Twitchell Island, California. 


\section{Conversion Factors}

SI to Inch/Pound

\begin{tabular}{lll}
\hline & Multiply & \multicolumn{1}{c}{ Bo obtain } \\
\hline centimeter $(\mathrm{cm})$ & Length & \\
meter $(\mathrm{m})$ & 0.3937 & inch (in.) \\
meter (m) & 3.281 & foot (ft) \\
\hline & 1.094 & yard (yd) \\
\hline hectare (ha) & Area & \\
hectare (ha) & 2.471 & acre \\
square meters $\left(\mathrm{m}^{2}\right)$ & 0.003861 & square mile $\left(\mathrm{mi}^{2}\right)$ \\
\hline
\end{tabular}

Temperature in degrees Celsius $\left({ }^{\circ} \mathrm{C}\right)$ may be converted to degrees Fahrenheit $\left({ }^{\circ} \mathrm{F}\right)$ as follows:

${ }^{\circ} \mathrm{F}=\left(1.8 x^{\circ} \mathrm{C}\right)+32$

Photosynthetically active radiation (PAR), a measure of radiant light power, is expressed in units of micromoles of photons per square meter per second $\left(\mu \mathrm{mol} / \mathrm{m}^{2} / \mathrm{s}\right)$, where $1 \mu \mathrm{mol}$ is equal to $0.000001 \mathrm{~mole}$, and $1 \mathrm{~mole}$ is equal to $6.022 \times 10^{23}$ photons.

\section{Abbreviations}

$\begin{array}{ll}\text { PAR } & \text { Photosynthetic active radiation } \\ \text { SSJ } & \text { Sacramento-San Joaquin } \\ \text { USGS } & \text { U.S. Geological Survey }\end{array}$


This page intentionally left blank. 


\title{
Water Temperature Differences by Plant Community and Location in Re-established Wetlands in the Sacramento- San Joaquin Delta, California, July 2005 to February 2008
}

\author{
By Kathryn L. Crepeau and Robin L. Miller
}

\begin{abstract}
Rates of carbon storage in wetlands are determined by the balance of its inputs and losses, both of which are affected by environmental factors such as water temperature and depth. In the autumn of 1997, the U.S. Geological Survey re-established two wetlands with different shallow water depths - about 25 and 55 centimeters deep- to investigate the potential to reverse subsidence of delta islands by preserving and accumulating organic substrates derived from plant biomass inputs over time. Because cooler water temperatures can slow decomposition rates and increase accretion of plant biomass, water temperature was recorded from July 2005 to February 2008 in the deeper of the two wetlands, where areas of emergent and submerged vegetation persisted throughout the study, to assess differences in water temperature between the two vegetation types. Water temperature was compared at three depths in the water column between areas of emergent and submerged vegetation and between areas near the water inflow and in the wetland interior in both vegetation types. The latter comparison was a way of evaluating the effect of the length of time water had resided in the wetland on water temperatures.

There were statistically significant differences in water temperature at all depths between the two vegetation types. Overall, in areas of emergent marsh vegetation, the mean water temperature at the surface was 1.4 degrees Celsius $\left({ }^{\circ} \mathrm{C}\right)$ less than it was in areas of submerged vegetation; however, when analyses accounted for the changes in temperature due to seasonal and diurnal cycles, differences in the mean water temperature between the vegetation types were even greater than this. For example, in the spring, the mean temperatures in areas of emergent marsh vegetation at the surface, midpoint, and near the sediment in the water column were 2.0, 2.3 , and $2.1^{\circ} \mathrm{C}$ less, respectively, than water temperatures
\end{abstract}

in areas of submerged vegetation. When diurnal changes in temperature were accounted for by comparing temperatures in mid-afternoon (at 3 p.m.), water-temperature differences were even greater than the seasonal means indicated. In areas of emergent vegetation, the mean temperatures were cooler than temperatures in areas of submerged vegetation at the surface, the mid-point, and near the sediment in the water column by 3.9, 3.6, and $2.3{ }^{\circ} \mathrm{C}$, respectively. Furthermore, from July 2005 through December 2006, water temperatures at the surface in the interior of the wetland were significantly cooler than in areas near the inflow supplying water from the San Joaquin River by $1.0^{\circ} \mathrm{C}$ in areas of submerged vegetation and by $1.1^{\circ} \mathrm{C}$ in areas of emergent vegetation.

\section{Introduction}

The land surface in the Sacramento-San Joaquin (SSJ) Delta has subsided more than 6 meters below sea level in some areas because its organic soils were leveed, drained, and farmed, which caused the soils to shrink and compact, and for the carbon stored in these soils to become permanently lost as a result of aerobic decomposition (Rojstaczer and Deverel, 1995). In 2010, 98 percent of the SSJ Delta was below sea level (Knowles, 2010). Extensive levee failure in an area subject to earthquakes and floods could result in saltwater intrusion into a freshwater system (Mount and Twiss, 2005) that supplies drinking, agricultural, and industrial water to more than two-thirds of California's population (Deverel and Rojstaczer, 1996). Continued subsidence increases the hydrostatic pressure on the levees, necessitating increased expenditures for levee maintenance and repair. For these reasons and more, reversing subsidence can be a beneficial management approach, especially in the most deeply subsided and vulnerable parts of the SSJ Delta. 
In 1997, the U.S. Geological Survey (USGS) built two wetlands in deeply subsided agricultural fields on Twitchell Island in the SSJ Delta of California to investigate the use of permanent shallow flooding to re-establish conditions favorable for carbon storage, which mitigates aerobic decomposition that causes continuing subsidence of organic soils. The two wetlands were flooded to different water depths - about 25 and 55 centimeters $(\mathrm{cm})$ deep- to determine how relatively small differences in water depth could affect carbon storage rates over time. From 1997 to 2008, gains in land-surface elevation averaged 4 centimeters per year (Miller and Fujii, 2011), primarily, from the accumulation of organic material; the average annual carbon storage rates were about 1 kilogram per square meter (Miller, 2011). Thus, the study demonstrated that re-establishing wetlands on subsided land in the SSJ Delta can be an effective way to reverse subsidence and reduce energy costs from pumping (which removes water from the below-sea-level islands) both in the short term, by the depth of flooding, and in the long term, as subsidence caused by the loss of the organic soil is mitigated and reversed by the accumulation of organic material over time.

In the USGS study of two wetlands on Twitchell Island, only areas with emergent marsh vegetation showed increased land-surface elevations (Miller and others, 2008). Areas of emergent marsh vegetation fixed more carbon dioxide through photosynthesis compared to areas of submerged and floating vegetation in the wetlands (Miller, 2011). Differences in water depth in the wetlands affected carbon fluxes, biomass inputs, and accretion rates, in part, because deeper water slowed the colonization and spread of emergent marsh vegetation, which was a driver of productivity and elevation gain in the wetlands. Also, the spread of emergent marsh vegetation was associated with changes in local environmental conditions, including water $\mathrm{pH}$, dissolved oxygen concentration, and temperature, all of which can affect decomposition rates, a primary factor in controlling preservation of carbon substrates and rates of accretion (Miller and Fujii, 2010 and 2011).

Temperature is an important environmental factor that affects many abiotic and biotic processes, including those involved in decomposition in wetlands (Bachand and Horne, 2000; Kadlec and Reddy, 2001; Neubauer and others, 2005). Water temperatures in wetlands can be affected by a variety of factors, including water sources, climate, water residence time in the wetland, and presence and type of vegetative cover (Mitsch and Gosselink, 1993; Akratos and Tsihrintzis, 2007). Decomposition rates increase in warmer water, in part, because the microbial population generally becomes more active as the temperature increases (Bachand and Horne, 2000; Kadlec and Reddy, 2001). Emergent marsh vegetation shades the water surface, decreasing the incidence of light, which is associated with cooler water temperatures (Miller and Fujii, 2010) that potentially slow decomposition and improve conditions for the preservation of organic matter (Miller and Fujii, 2011). In contrast, in areas of submerged vegetation, the water surface is exposed to sunlight, which warms the water column (Miller and Fujii, 2010). In a study in Sacramento County of wastewater-treatment wetlands with similar vegetation, water temperatures differed according to the length of time the water was in the wetland; water cooled as it travelled from inflows to outflows (Nolte Associates, Inc., 1999).

In the wetlands re-established by the USGS on Twitchell Island in the SSJ Delta (fig.1), discrete measurements of water temperature, taken during sampling events in the first several years after flooding, showed statistically significant differences in water and soil temperatures between areas of emergent and submerged vegetation. In order to assess differences in water temperature by vegetation type and the length of time the water had resided in the wetland, as represented by location along the water flow path through the wetland, the USGS installed temperature sensors and continuously recording data loggers in the $55-\mathrm{cm}$ deep wetland because areas with the two different plant communities persisted in that wetland throughout the study (Miller and Fujii, 2010 and 2011).

\section{Purpose and Scope}

The purpose of this report is to summarize continuous water-temperature data collected from July 2005 to February 2008 by the USGS in a re-established wetland on Twitchell Island in the SSJ Delta, California (fig. 1). Temperature sensors were placed at eight sites (fig. 2) at three water depths at each site (fig. 3) to assess the effect of location and wetland plant communities on water temperature. Data were collected every 30 minutes. To account for temporal effects, seasonal and diurnal effects on water temperature were assessed in the context of plant community, location in the wetland, and depth in the water column. Because temperature affects many important processes, such as nutrient cycling, evapotranspiration, and decomposition, these data can be useful to a variety of studies, modeling efforts, and management decisions regarding wetland habitat, restoration, and monitoring.

\section{Site Description}

The study site was a 6-hectare agricultural field near the center of Twitchell Island in the Sacramento-San Joaquin River Delta of California ( $38^{\circ} 6^{\prime} \mathrm{N}, 121^{\circ} 39^{\prime} \mathrm{W}$, fig. 1). The climate is Mediterranean, with cool, rainy winters and hot, dry summers, and the growing season can extend from February to November. The field was leveled and split into two similar areas by a berm. In early autumn of 1997, the areas were flooded to two different shallow water depths that allowed for growth of emergent marsh vegetation-about $25 \mathrm{~cm}$ deep and about $55 \mathrm{~cm}$ deep (fig. 2). Four boardwalks were built in each wetland prior to flooding to facilitate sampling without disturbing the water, vegetation, or substrate. This study was carried out only in the deeper wetland because the shallower wetland was completely covered by emergent marsh vegetation within two growing seasons, while areas of submerged and floating vegetation (fig. 4) persisted in the $55-\mathrm{cm}$ deep wetland during the entire study (Miller and Fujii, 2010). 


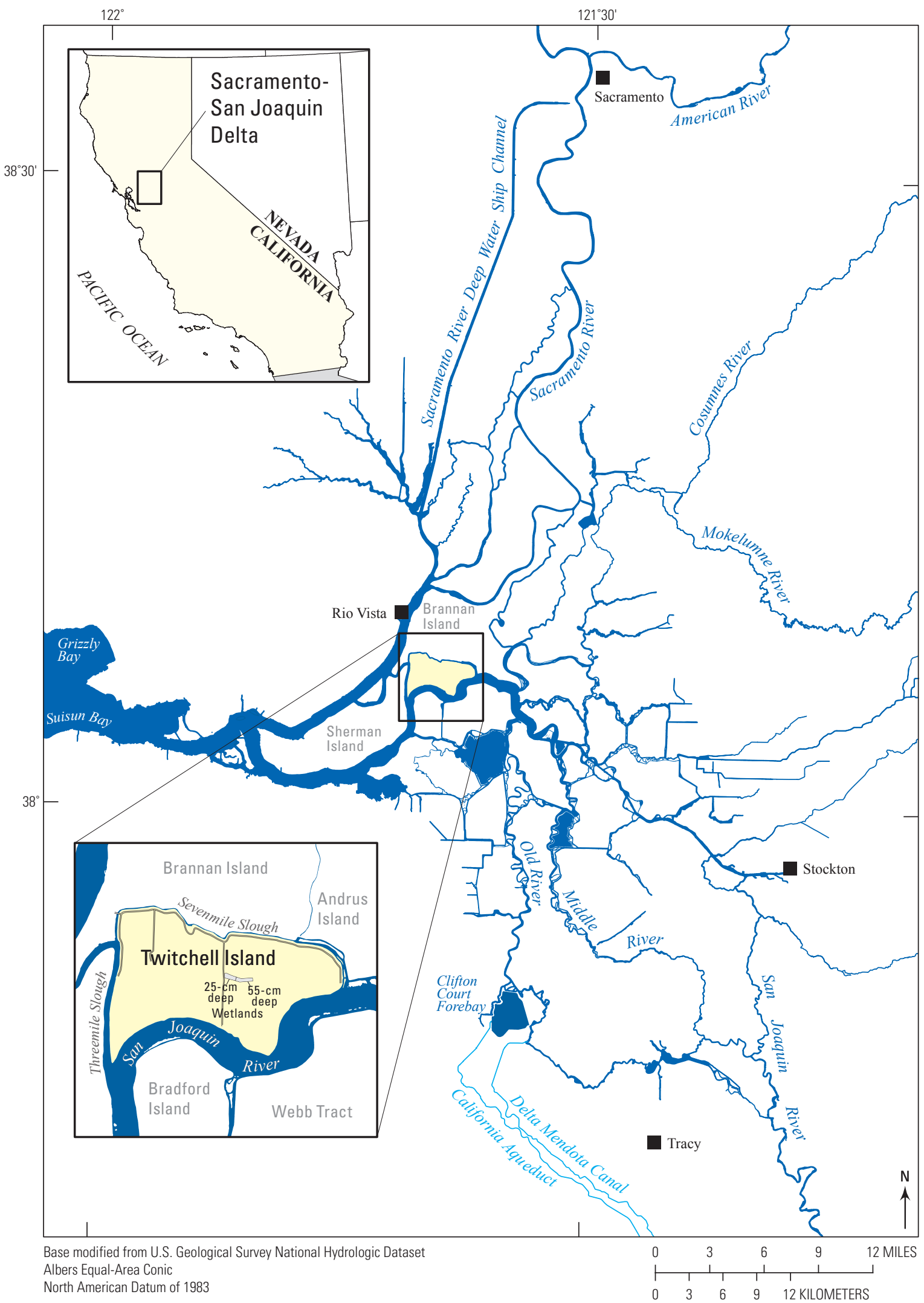

Figure 1. The location of Twitchell Island in the Sacramento-San Joaquin River Delta of California. 


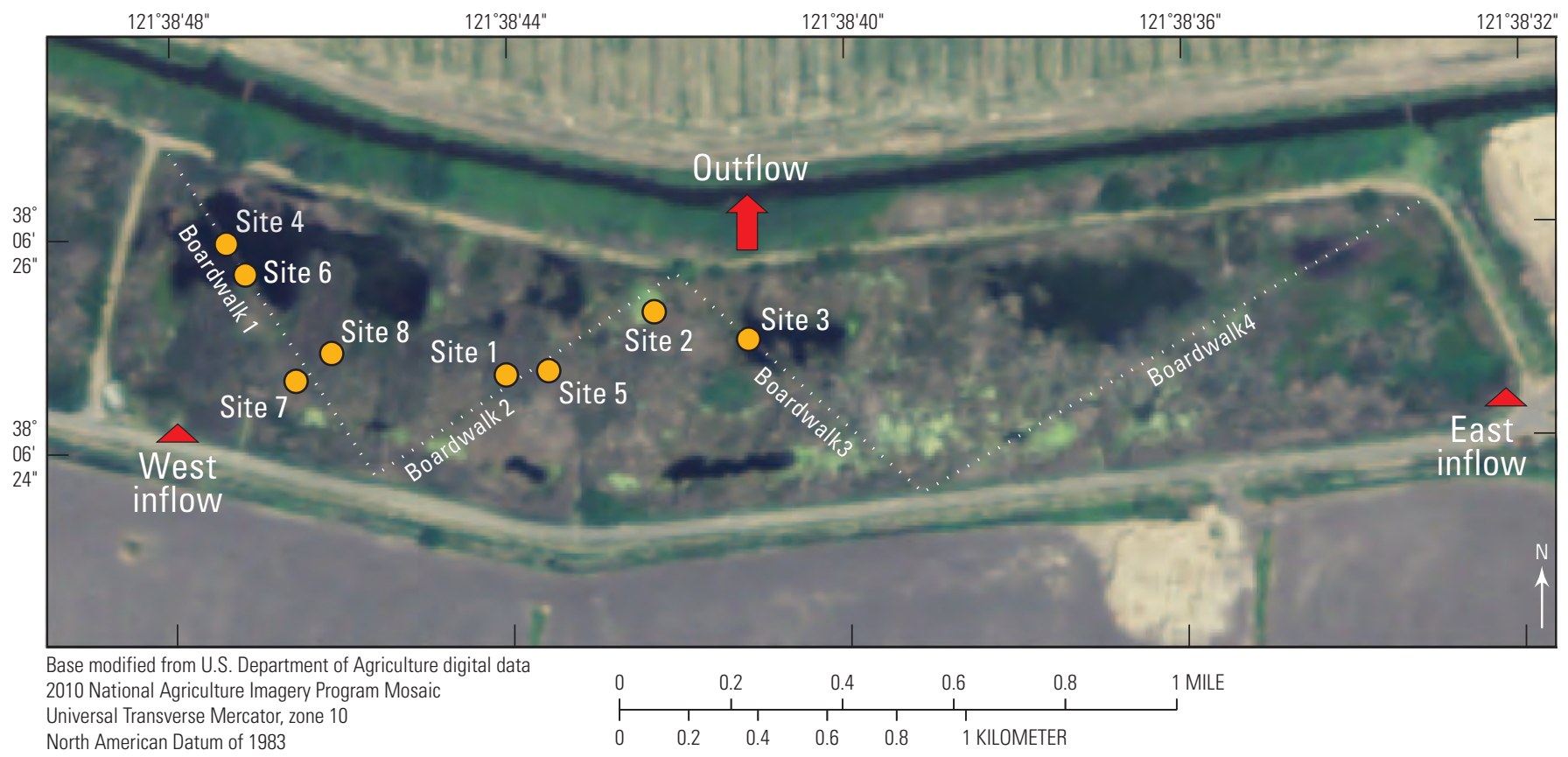

Figure 2. Aerial photo of 55-centimeter deep wetland on Twitchell Island, California, showing the locations of water-temperature sensors.

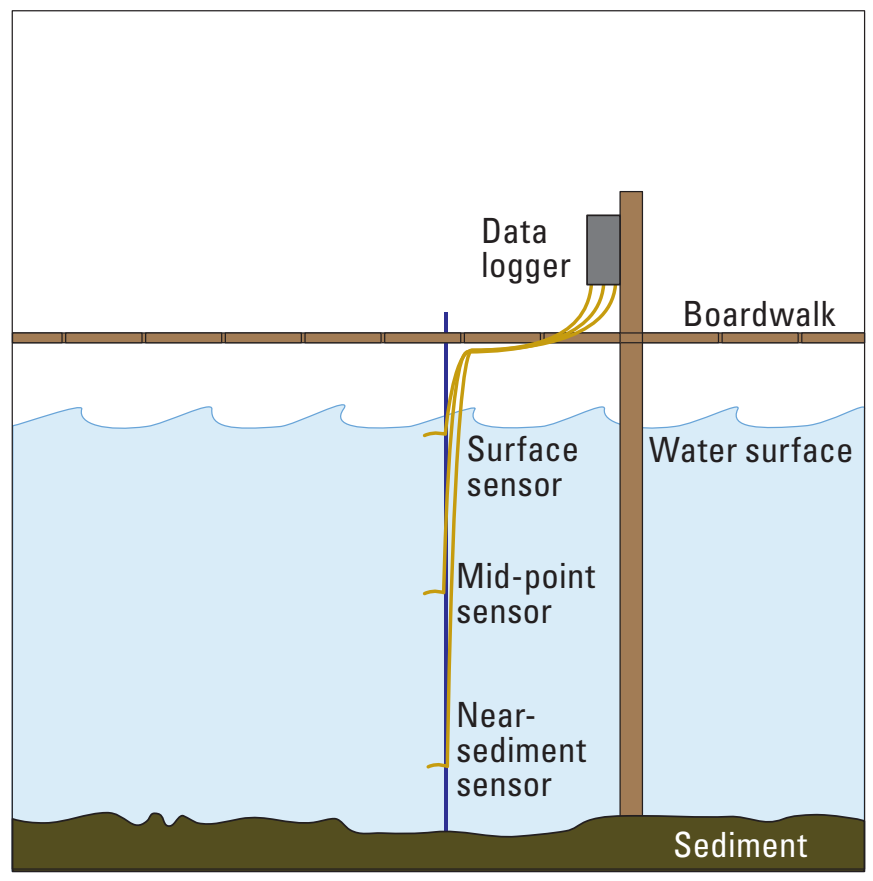

Figure 3. Placement of temperature sensors in the water column. Not drawn to scale and vegetation not shown. 


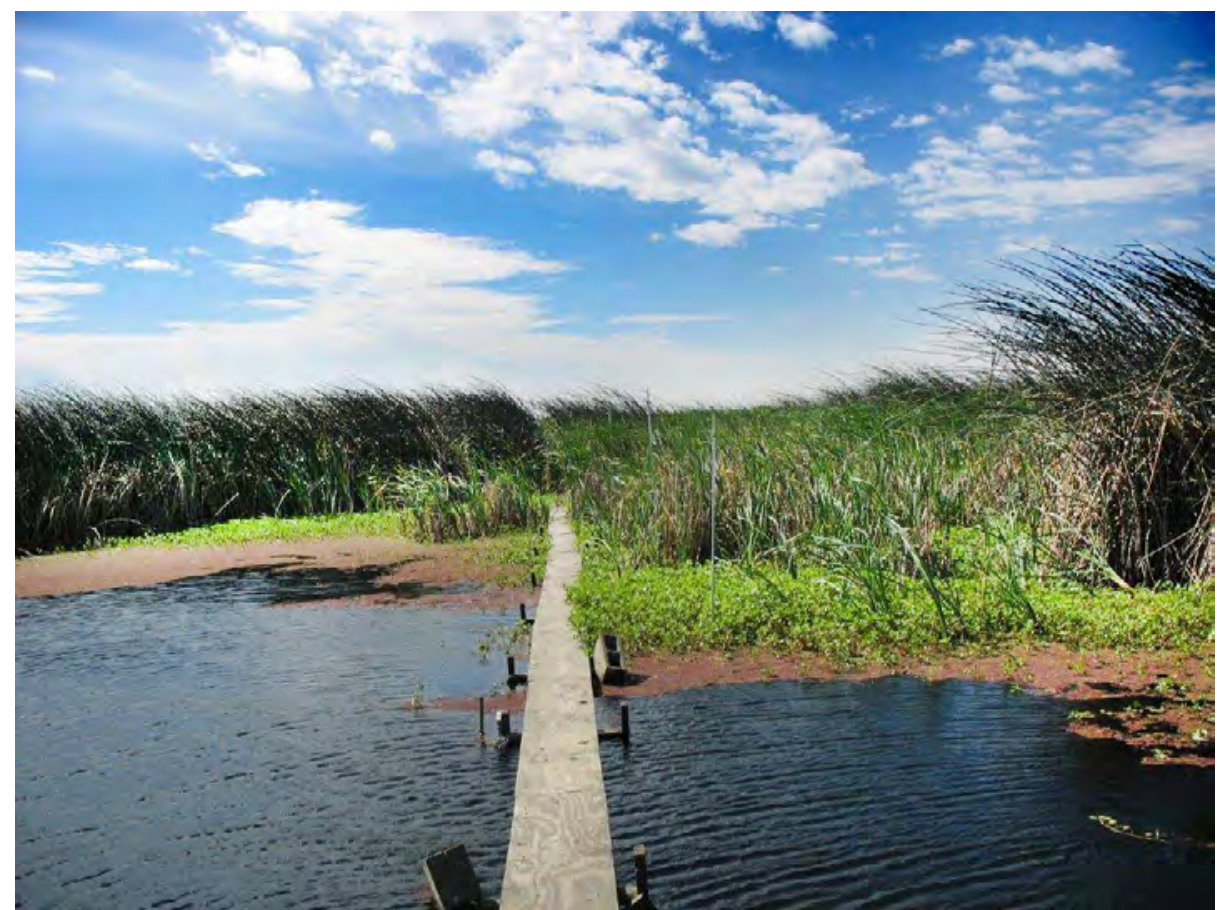

Figure 4. Areas of emergent and submerged and floating vegetation in the 55-centimeter deep wetland. Photo taken by Robin L. Miller.

In September 1997, shortly before flooding, Schoenoplectus acutus stems and rhizomes, collected from stands on the island, were planted every 2 meters in five 10 - by 25 -meter blocks in the eastern half of each wetland. In the first year after flooding (1998), Typha spp. (cattails) colonized the site, the source of which was likely to have been windblown seed from plants in surrounding ditches. The $55 \mathrm{~cm}$ deep wetland was composed of areas of emergent marsh vegetation (primarily, Schoenoplectus acutus and Typha spp.) and submerged (including Myriophyllum, Potamogetan, Egeria, and Ceratophyllum) and floating (Lemna, Azolla, and Lugwigea) vegetation (Miller and Fujii, 2010).

Fresh water from the San Joaquin River was continuously piped into the wetlands through inflows on the southwest and southeast corners of the continuously flooded wetlands (fig. 2). Adjustable weirs to control the water depth were installed at the outflows, which were near the center of the north side of the wetlands. Mean inflow rates to the wetlands, measured from October 1998 through September 2001, were $900 \pm$ 200 liters per minute (Gamble and others, 2003). Based on this inflow rate, the calculated mean water-residence time for the $55 \mathrm{~cm}$ deep wetland was 13 days (Miller and others, 2008). In early 2005 , inflow rates to the wetlands were reduced to minimize outflow. In January 2007, the southwest inflow was closed so that, during the final 13 months of the study, the San Joaquin River water entered the wetland only through the southeast inflow, which altered the direction of water flow and changed the length of time water resided in the wetland relative to each measurement site.

\section{Methods}

\section{Data Collection}

In the $55 \mathrm{~cm}$ deep wetland, Hobo data loggers (H8 Outdoor Industrial 4-Channel, Onset Computer Corporation, Bourne, Massachusetts) were placed at eight sites, temperature sensors were deployed at three depths in the water column at each site (fig. 3), and, from July 2005 to February 2008, measurements were recorded every half hour. Four sites were in the submerged vegetation and four were in the emergent vegetation. Of the four sites in each plant community (submerged and emergent vegetation), two were closer to the west inflow and two were closer to the interior of the wetland (fig. 2) as a way to evaluate the effect of the length of time the water had been in the wetland on water temperature while controlling for the effect of plant community. Sites were paired so there would be a backup in case of sensor or logger failure.

Prior to deployment, logger and sensor temperature accuracy was checked against an ice-water control and calibrated-thermometer readings. The loggers were regularly maintained, and sensors were replaced, as necessary, during twice-monthly site visits, when data were downloaded onto a storage module prior to transfer to a computer, where they were compiled in Microsoft Excel ${ }^{\circledR}$ spreadsheets (appendix 1). The data were archived in ADAPS (Automated Data Processing System) and can be accessed through the National Water Information System website (NWISweb) at $h t t p: / /$ waterdata.usgs.gov. The raw data were evaluated visually, in graphs, and statistically, by evaluations of spread and outliers, to remove invalid data that resulted from logger or sensor failure. There are two periods with no data from any of the sites: November 10-30, 2005, and February 23April 19, 2006. No data were collected after December 18, 2006, for site 5 (table 1) and after March 2, 2007, for site 2.

At each of the data logger sites, temperature sensors were placed at three depths in the water column: (1) the surface, which was $2 \mathrm{~cm}$ below the water surface; (2) the mid-point, which was midway between the sediment and the water surface; and (3) near the sediment (fig. 3). The mid-point and near-sediment sensors were placed at different mean water depths in the two vegetation types (table 1) because the mean water depths differed between the two vegetation types as a result of several years with greater accretion of organic material in areas of emergent marsh vegetation 
compared to areas of submerged vegetation (Miller and others, 2008; Miller and Fujii, 2011). The mid-point sensor depths ranged from 13 to $23 \mathrm{~cm}$ below the water surface in areas of emergent marsh vegetation and from 23 to $36 \mathrm{~cm}$ below the water surface in areas of submerged vegetation. The near sediment sensor depths ranged from 28 to $41 \mathrm{~cm}$ below the water surface in the emergent marsh vegetation and from 56 to $63.5 \mathrm{~cm}$ below the water surface in the submerged vegetation.

At each of the sites, photosynthetic active radiation (PAR) was measured just above the water surface by using a portable PAR meter to quantify the differences in exposure to sunlight among the sites. Thirteen PAR measurements were made beginning on July 13, 2005, and ending November 10, 2005 (appendix 2).

\section{Data Analysis}

The data were assessed statistically with univariate, distribution, and frequency tests by using the $\mathrm{SAS}^{\circledR}$ software suite (Statistical Analysis Systems Institute, http://www. sas.com). As previously described, data were checked for outliers that indicated equipment failure, and any outliers were deleted from the dataset prior to doing the statistical tests for significant differences. Differences in water temperature by wetland plant community and by location, to represent the time water had resided in the wetland, were analyzed by mixed model analysis of variance (ANOVA) to account for repeated measurements over time. Temperature differences between locations and plant communities were assessed independently of differences attributed to season or time-of-day by analyzing data for all locations over comparable seasons and comparable times of day. Measurements designed to assess the effect of location on water temperature were limited to the first 2 years of the study (2005 and 2006) because subsequent changes in management of the water inflows altered the water flow paths and the length of time water was in the wetland relative to each site. The ANOVA p-values $(p)$ are reported to show statistically significant differences between plant communities and locations, where a significance level of 0.05 was used to determine the significance of all tests ( $p$ less than 0.05 was considered significant). The standard error for all means was less than \pm 0.1 degree Celsius $\left({ }^{\circ} \mathrm{C}\right)$ except as otherwise noted.

\section{Results}

The presence of emergent vegetation was associated with significantly lower water temperatures compared to temperatures in areas of submerged vegetation at all water depths (ANOVA, $p$ less than 0.05 for all comparisons, table 2). Over the entire sampling period, the mean water temperatures in areas of emergent vegetation at the surface, the mid-point, and near the sediment of the water column were $1.4,0.9$, and $0.4{ }^{\circ} \mathrm{C}$ less, respectively, than in areas of submerged vegetation. Even greater temperature differences than these, however, were observed when the minimums or the maximums between sites of different plant communities were compared (table 2). Water temperature measurements, from sensors at the surface, at the mid-point, and near the sediment in the water column for each of the four emergent vegetation and the four submerged vegetation sites from July 2005 to February 2008, are reported in appendix 1.

Table 1. Site number, site identification, sensor location, sensor depth, and measured photosynthetically active radiation in the 55-centimeter deep wetland, Twitchell Island, California.

[Abbreviations: cm, centimeter; PAR, photosynthetically active radiation; $\mu \mathrm{mol} / \mathrm{m}^{2} / \mathrm{sec}$, micromole per meter squared per second; ${ }^{\circ}$, degree; ', minute; ", second]

\begin{tabular}{|c|c|c|c|c|c|c|c|c|}
\hline 1 & 380624121384401 & Emergent marsh & Interior & $38^{\circ} 06^{\prime} 24.65^{\prime \prime}$ & $121^{\circ} 38^{\prime} 44.04^{\prime \prime}$ & 23 & 38 & 6 \\
\hline 8 & 380624121384602 & Emergent marsh & Near inflow & $38^{\circ} 06^{\prime} 24.85^{\prime \prime}$ & $121^{\circ} 38^{\prime} 46.36^{\prime \prime}$ & 15 & 29 & 80 \\
\hline 2 & 380625121384301 & Submerged & Interior & $38^{\circ} 06^{\prime} 25.37^{\prime \prime}$ & $121^{\circ} 38^{\prime} 42.63^{\prime \prime}$ & 33 & 56 & 1,475 \\
\hline 3 & 380625121384302 & Submerged & Interior & $38^{\circ} 06^{\prime} 24.99^{\prime \prime}$ & $121^{\circ} 38^{\prime} 41.28^{\prime \prime}$ & 36 & 63.5 & 1,420 \\
\hline 4 & 380626121384701 & Submerged & Near inflow & $38^{\circ} 06^{\prime} 25.95^{\prime \prime}$ & $121^{\circ} 38^{\prime} 47.46^{\prime \prime}$ & 32 & 56 & 1,430 \\
\hline
\end{tabular}


Table 2. Summary of water temperature data at three depths for submerged vegetation compared to emergent vegetation, Twitchell Island, California, July 2005 to February 2008.

[All comparisons of means were significant at $\mathrm{p}<0.05$; standard error for all means was less than \pm 0.1 . Abbreviations: $\mathrm{N}$, number of samples; ${ }^{\circ} \mathrm{C}$, degree Celsius]

\begin{tabular}{|c|c|c|c|c|c|c|c|c|c|c|c|}
\hline \multirow{2}{*}{$\begin{array}{l}\text { Water } \\
\text { depth }\end{array}$} & \multicolumn{4}{|c|}{ Water temperature in submerged vegetation } & \multicolumn{4}{|c|}{ Water temperature in emergent vegetation } & \multicolumn{3}{|c|}{ Difference in water temperature ${ }^{1}$} \\
\hline & $\mathbf{N}$ & $\begin{array}{c}\text { Mean } \\
\left({ }^{\circ} \mathrm{C}\right)\end{array}$ & $\begin{array}{c}\text { Minimum } \\
\left({ }^{\circ} \mathrm{C}\right)\end{array}$ & $\begin{array}{l}\text { Maximum } \\
\quad\left({ }^{\circ} \mathrm{C}\right)\end{array}$ & $\mathbf{N}$ & $\begin{array}{l}\text { Mean } \\
\left({ }^{\circ} \mathrm{C}\right)\end{array}$ & $\begin{array}{l}\text { Minimum } \\
\quad\left({ }^{\circ} \mathrm{C}\right)\end{array}$ & $\begin{array}{l}\text { Maximum } \\
\quad\left({ }^{\circ} \mathrm{C}\right)\end{array}$ & $\begin{array}{c}\text { Means } \\
\left({ }^{\circ} \mathrm{C}\right)\end{array}$ & $\begin{array}{c}\text { Minimums } \\
\left({ }^{\circ} \mathrm{C}\right)\end{array}$ & $\begin{array}{c}\text { Maximums } \\
\left({ }^{\circ} \mathrm{C}\right)\end{array}$ \\
\hline Mid-point & 116,919 & 14.2 & 2.5 & 27.9 & 121,500 & 13.3 & 1.6 & 26.0 & 0.9 & 0.9 & 1.9 \\
\hline Near-sediment & 97,982 & 13.6 & 2.5 & 24.0 & 116,228 & 13.2 & 0.3 & 23.2 & 0.4 & 2.2 & 0.8 \\
\hline
\end{tabular}

${ }^{1}$ Water temperature of submerged vegetation minus water temperature of emergent vegetation for the means, minimums, and maximums.

Median PAR values (table 1) were two orders of magnitude less in areas of emergent vegetation compared to PAR values in areas of submerged vegetation. Also, differences in PAR between the vegetation types were greatest after the emergent marsh canopy closed during summer and were less following marsh senescence and the opening of the canopy again during winter.

\section{Seasonal Differences in Water Temperature by Plant Community}

Greater differences in the water temperature were evident between the plant communities when data analyses accounted for seasonal variations compared to differences in the overall means. The seasons were defined as spring, from March equinox to June solstice; summer, from June solstice to September equinox; autumn, from September equinox to December solstice; and winter, from December solstice to March equinox. During each of the four seasons, water temperatures were significantly cooler in areas of emergent vegetation compared to temperatures in areas of submerged vegetation at the surface, the mid-point, and near the sediment in the water column by a range of $1.7-2.0,0.9-2.3$, and $0.2-2.1{ }^{\circ} \mathrm{C}$ (ANOVA, $p$ less than 0.05 for all comparisons), respectively (table 3 ). The maximum temperatures were in the spring and summer (table 3 ).

In the spring, the mean water temperature at all depths was at least $2{ }^{\circ} \mathrm{C}$ cooler (table 3 ) in areas of emergent vegetation than in areas of submerged vegetation. The water temperature near the sediment was warmer in areas of submerged vegetation than in areas of emergent vegetation, even though the sensors were placed 56-63.5 and 28-41 cm below the water surface, respectively (tables 1 and 3 ). This most likely happened because solar radiation heated the unshaded water surface in areas of submerged vegetation more than the shaded water suface in areas of emergent vegetation.

Table 3. Summary of water temperature data at three depths, by season, for submerged vegetation compared to emergent vegetation, Twitchell Island, California, July 2005 to February 2008.

[All comparisons of means were significant at $\mathrm{p}<0.05$; standard error for all means was less than \pm 0.1 . Abbreviations: $\mathrm{N}$, number of samples; ${ }^{\circ} \mathrm{C}$, degree Celsius]

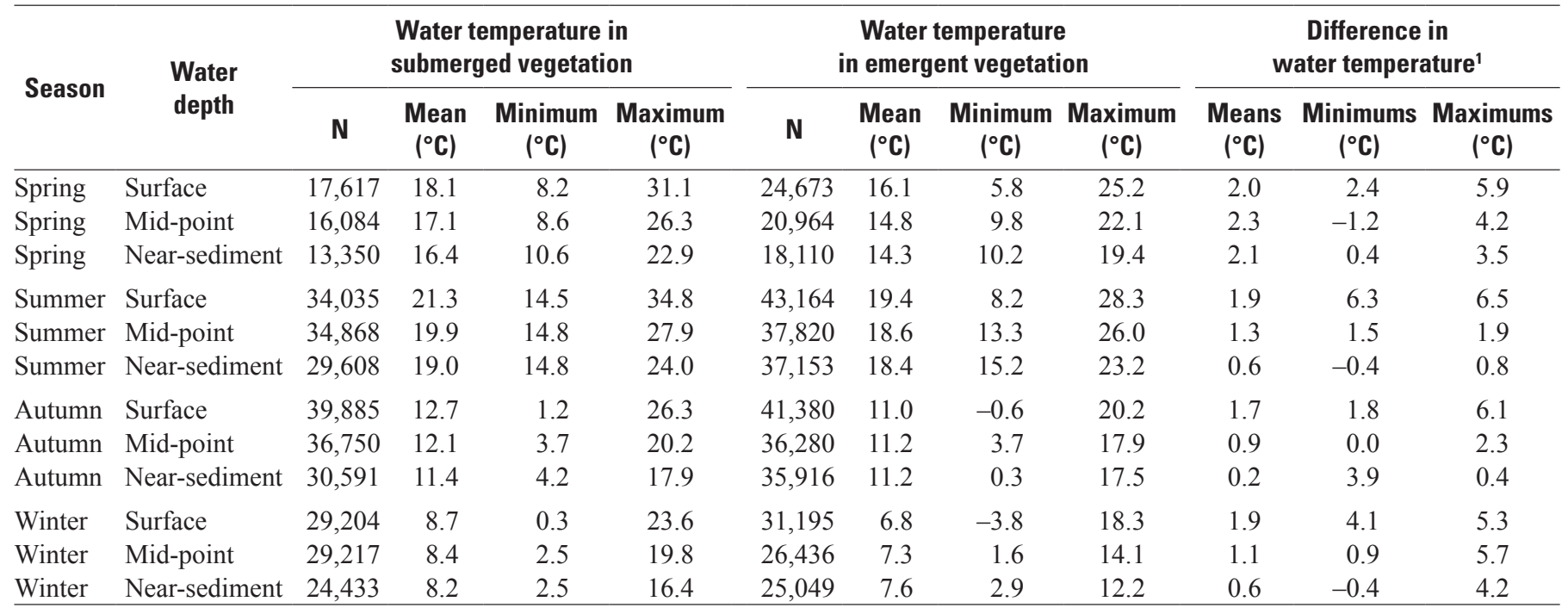

\footnotetext{
${ }^{1}$ Water temperature of submerged vegetation minus water temperature of emergent vegetation for the means, minimums, and maximums.
} 
Daytime water temperatures in areas of emergent vegetation were cooler than the water temperatures in areas of submerged vegetation, as illustrated by several "snapshots" of water temperature at different times of the year (fig. $5 A-C$ ). The greatest differences in temperature between areas of emergent and submerged vegetation were at the water surface in summer. For example, the water temperature at the surface was $7.1^{\circ} \mathrm{C}$ cooler in areas of emergent vegetation than in areas of submerged vegetation on August 28, 2005, at 3:30 p.m. (fig. 5A). Even in the autumn and winter, the surface temperatures could range from 4 to $6{ }^{\circ} \mathrm{C}$ cooler during the warmest part of the day in areas of emergent vegetation compared to temperatures in areas of submerged vegetation (fig. $5 B, C$ ).

\section{Diurnal Differences in Water Temperature by Plant Community}

The diurnal temperature cycle was approximately sinusoidal, particularly for the surface and often for the midpoint of the water column, with lows in the early morning and highs in the mid- afternoon (figs. $5 A-C$ ). Because time is needed for heat from the solar radiation to propagate through the water, temperature maximums were reached earlier in the day at the surface than at the mid-point or near the sediment in the water column. For example, on August 25, 2005, in areas of submerged vegetation, surface temperature peaked at 3:30 p.m.; the mid-point, at 9:30 p.m.; and near the sediment, at 11:30 p.m. (fig $5 A$ ). In areas of emergent vegetation, surface

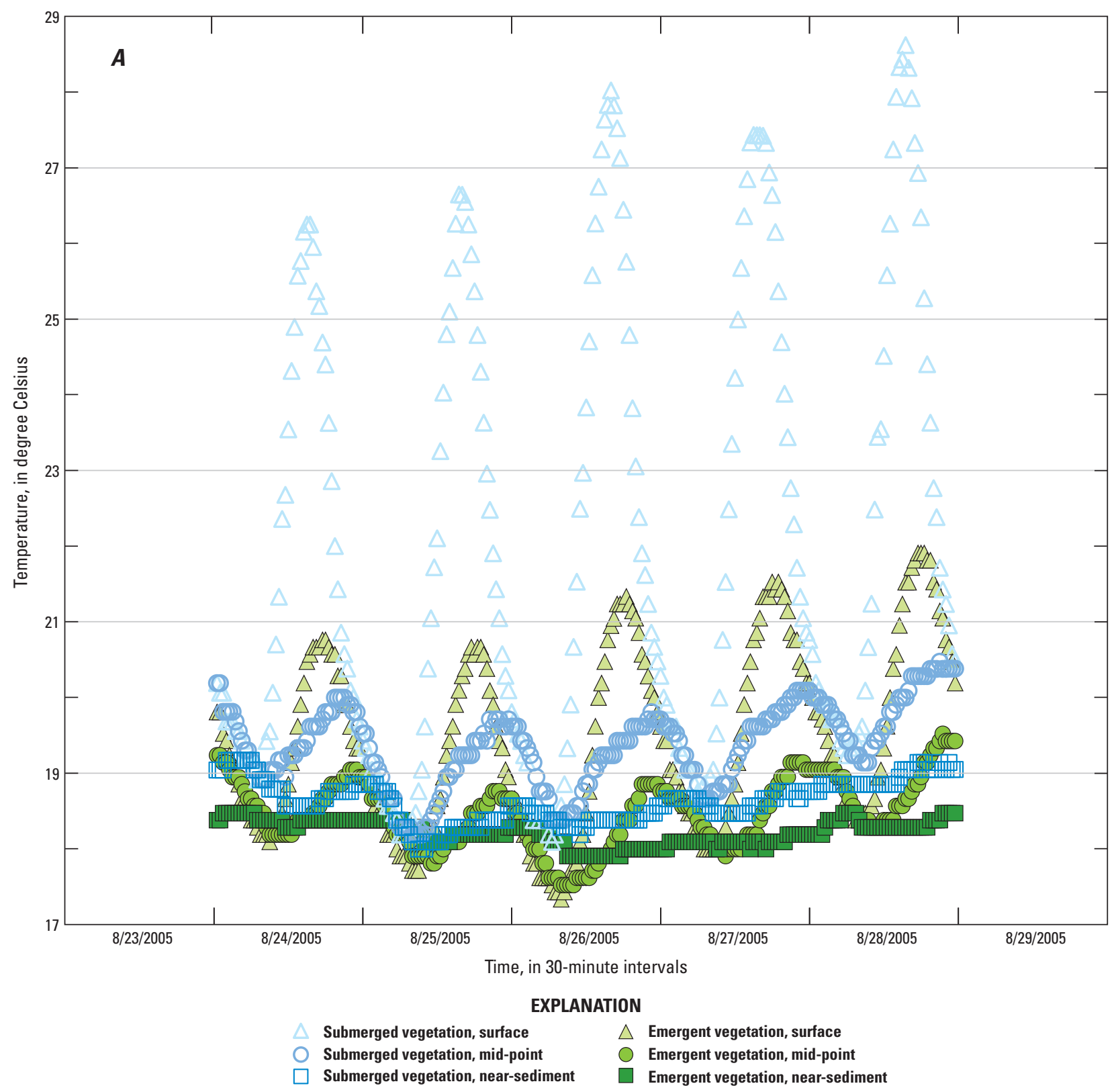

Figure 5. Mean water temperatures in areas of emergent and submerged vegetation at different times of year, Twitchell Island, California: A, August 24-28, 2005; B, December 8-12, 2005; and C, March 10-14, 2007. 
temperatures peaked at 5:30 p.m., about 2 hours later in the day than in areas of submerged vegetation, but lower in the water column maximum temperatures were reached at the same time as in submerged vegetation. Mid-point temperatures peaked at 9:30 p.m., and temperatures near the sediment peaked at 11:30 p.m.

The greatest diurnal range in water temperature took place at the surface in areas of submerged vegetation during summer. For example, on August 26, 2005 (fig. 5A), the water temperature at the surface in areas of submerged vegetation ranged from $18.1^{\circ} \mathrm{C}$ at $6: 30$ a.m. to $28.0^{\circ} \mathrm{C}$ at 4 p.m. - a difference of about $10^{\circ} \mathrm{C}$. In contrast, in areas of emergent vegetation, surface temperatures ranged from a minimum of $17.3^{\circ} \mathrm{C}$ to a maximum of $21.2{ }^{\circ} \mathrm{C}-\mathrm{a}$ difference of only about
$4{ }^{\circ} \mathrm{C}$. For the entire study period, the mean water temperatures at the surface in areas of emergent vegetation at 3 p.m. were significantly cooler than they were in areas of submerged vegetation in spring, summer, autumn, and winter by $3.9,4.3$, 3.4 , and $2.7^{\circ} \mathrm{C}$, respectively (ANOVA, $p$ less than 0.05 for all comparisons, table 4). At the mid-point and near the sediment in the water column, the mean water temperatures in areas of emergent vegetation were also significantly cooler at 3 p.m. than in areas of submerged vegetation during all four seasons, but the greatest temperature differences at these depths were in spring, rather than in summer (table 4).

For most of the year, the water temperature near the sediment in areas of emergent vegetation was the coldest in the wetland. For some periods in the winter, however, the

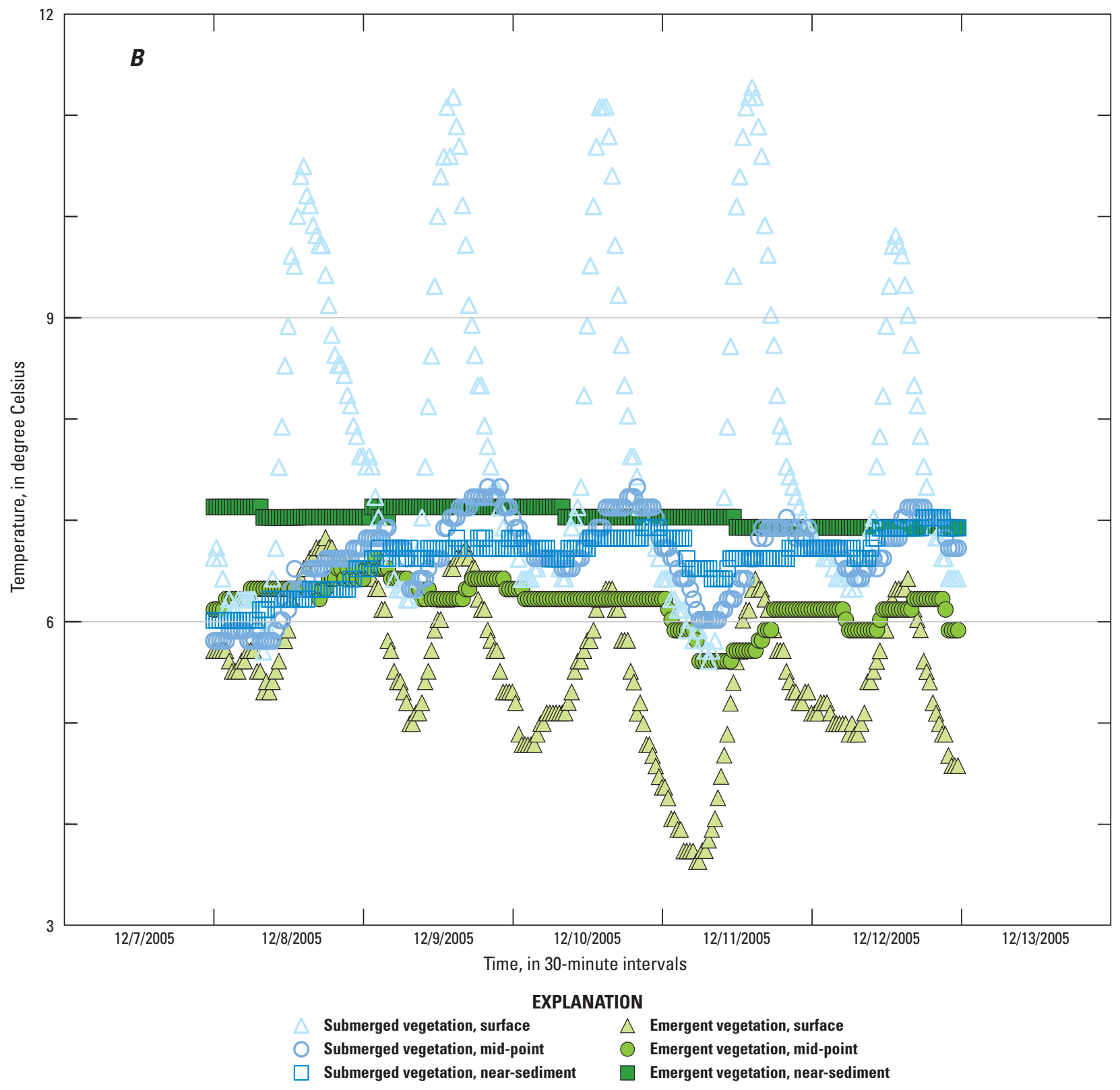

Figure 5. - Continued 


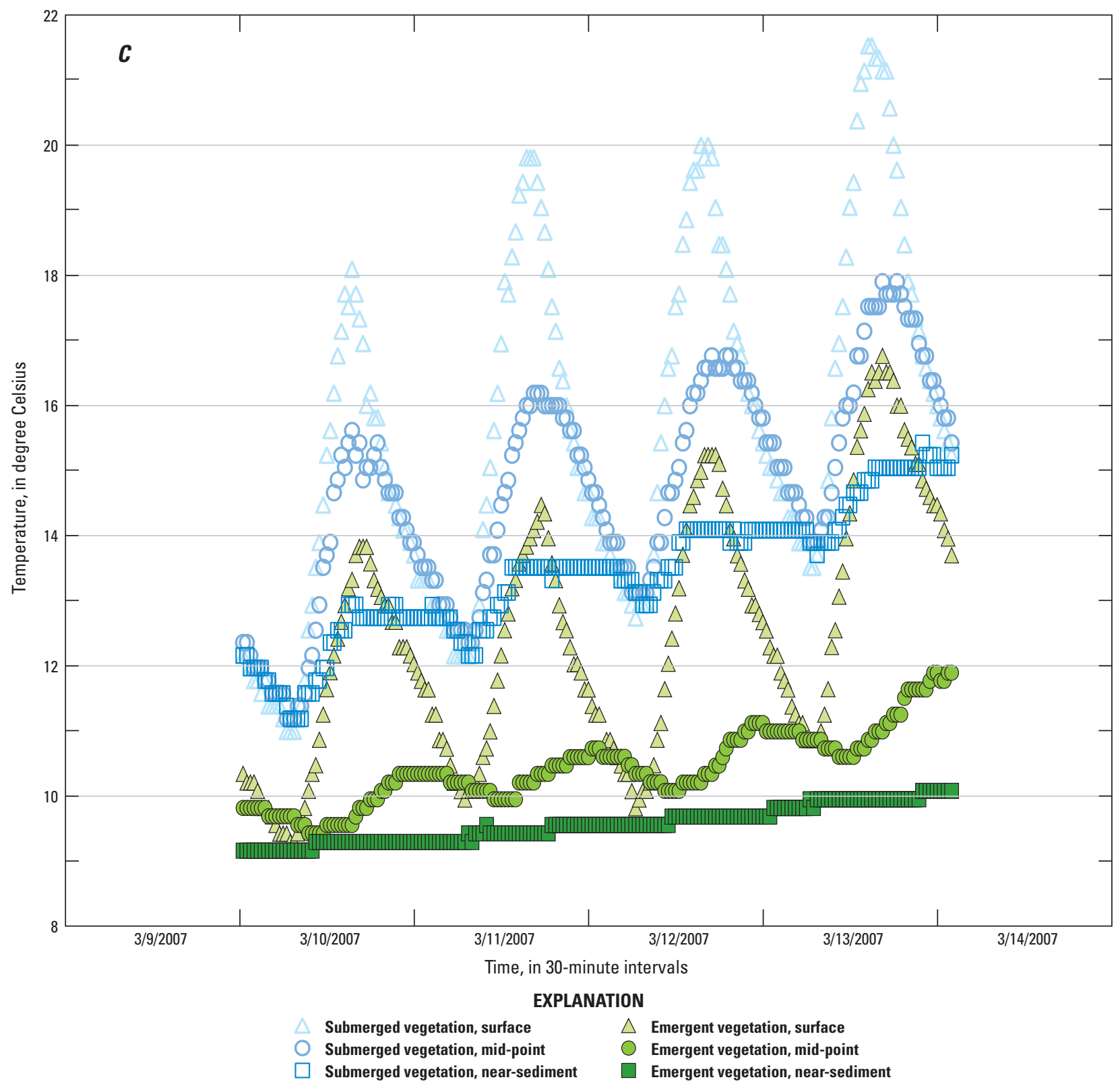

Figure 5. - Continued

water temperature near the sediment in areas of emergent vegetation was warmer compared to water temperatures higher in the water column (fig. $5 B$ ). During this time, at the warmest part of the day, the temperatures nearest the sediment in areas of emergent vegetation were warmer than in all the other locations, except for the surface temperatures in areas of submerged vegetation. In contrast, the surface temperatures in areas of emergent vegetation often were colder than elsewhere in the wetland during the winter months. For example, in December 2005, the mean surface temperature in areas of emergent vegetation ranged from a low of $3.6^{\circ} \mathrm{C}$, at 5:30 a.m., to a high of $6.8^{\circ} \mathrm{C}$, at $6 \mathrm{p} . \mathrm{m}$. In contrast, the mean surface temperature in areas of submerged vegetation ranged from a low of $5.8{ }^{\circ} \mathrm{C}$, at 5:30 a.m., to a high of $11.3{ }^{\circ} \mathrm{C}$, at 2:30 p.m., during the same week in December (fig. $5 B$ ).

\section{Differences in Water Temperature by Location in Wetland}

The water temperature was not only cooler in areas of emergent vegetation, but it was also cooler in the interior of the wetland, where the water had resided longer compared to areas near the inflow. In areas of emergent and submerged vegetation in the interior of the wetland, the water temperature was significantly cooler than in areas with the same vegetation type closer to the inflow. Using measurements from the first 2 years of the study (before the water flow path was changed), the mean water temperatures in areas of submerged vegetation at the surface, mid-point, and near the sediment were 1.0, 1.5 , and $1.5^{\circ} \mathrm{C}$ cooler, respectively, in the interior of the wetland than near the inflow (ANOVA, $p$ less than 0.05 for 


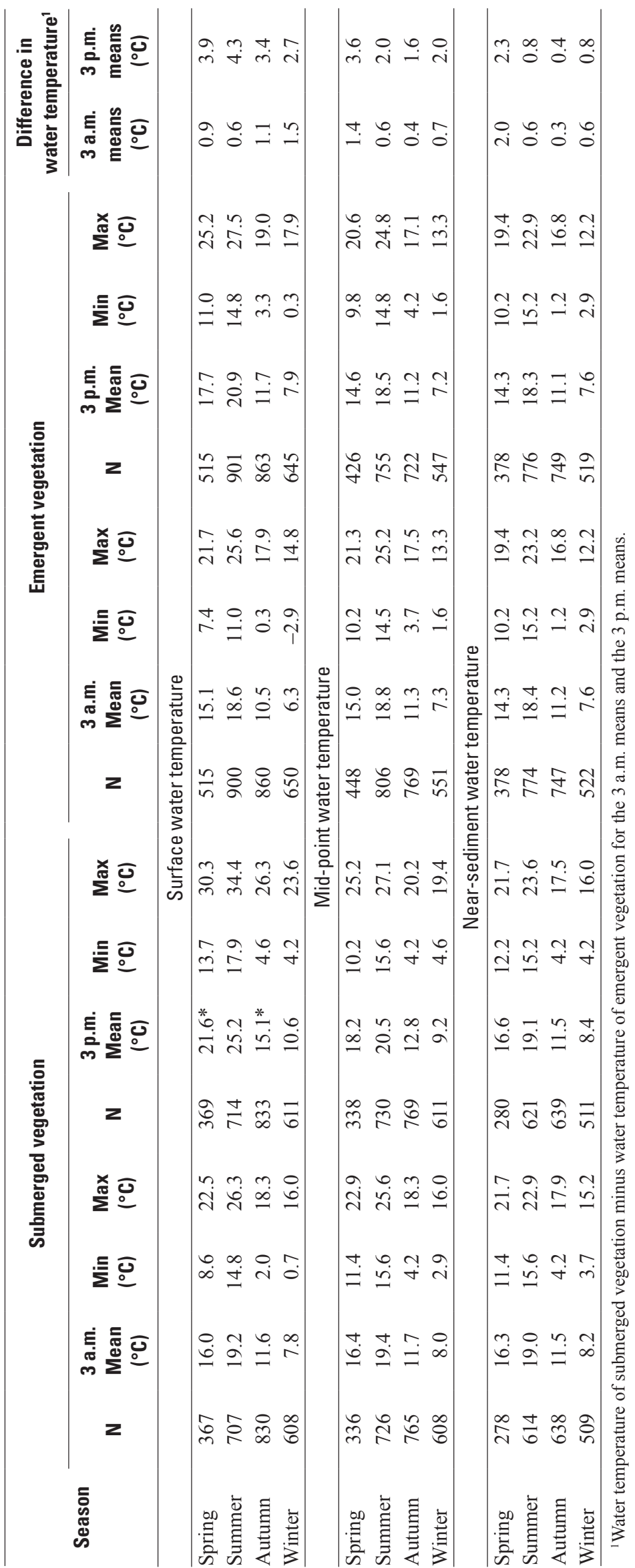


all comparisons, table 5). In areas of emergent vegetation, the mean water temperatures at the surface, mid-point, and near the sediment were $1.1,0.6$, and $1.1^{\circ} \mathrm{C}$ cooler, respectively, in the interior of the wetland than near the inflow (ANOVA, $p$ less than 0.05 for all comparisons, table 5).

During summer, water temperatures in areas of emergent and submerged vegetation were cooler in the wetland interior compared to water temperatures in areas near the inflows (fig. $6 A$ and $B$ ). For example, on August 26, 2005, the maximum water temperature in areas of emergent vegetation in the wetland interior was about $2{ }^{\circ} \mathrm{C}$ cooler at the surface of the water column, $1{ }^{\circ} \mathrm{C}$ cooler at the mid-point, and $0.5^{\circ} \mathrm{C}$ cooler near the sediment compared to temperatures in areas of similar vegetation near the inflow (fig. 6A). Similarly, the maximum water temperature in areas of submerged vegetation was about $4{ }^{\circ} \mathrm{C}$ cooler at the surface of the water column, $2{ }^{\circ} \mathrm{C}$ cooler at the mid-point, and $1{ }^{\circ} \mathrm{C}$ cooler near the sediment in the wetland interior than in areas of similar vegetation near the inflow (fig. 6B).

\section{Summary}

The U.S. Geological Survey re-established two wetlands on Twitchell Island, California, that had different shallow water depths to investigate the potential to reverse subsidence of delta islands by preserving and accumulating organic material derived from plant biomass inputs over time. To help assess the effects of differences in wetland vegetation on water temperatures, water-temperature data were collected in the deeper of the two wetlands, from July 2005 to February 2008 , by using paired temperature sensors and loggers placed in areas of submerged vegetation and emergent vegetation near the inflow, where the water enters the wetland from the river, and in areas of the same vegetation types in the wetland interior, where the water had been in the wetland longer than that by the inflow. Temperature sensors were placed at three depths in the water column at each site: the surface, mid-point, and near the sediment.

The data showed that the presence of emergent vegetation was associated with significantly lower water temperatures compared to water temperatures in areas of submerged vegetation. Overall, the mean water temperature at the surface was $1.4^{\circ} \mathrm{C}$ less in areas of emergent marsh vegetation than in areas of submerged vegetation. When seasonal differences were included in the data analysis, during the spring and summer, there were even lower water temperatures in areas of emergent vegetation than in areas of submerged vegetation. In the spring, the mean temperatures at the surface, mid-point, and near the sediment in the water column were $2.0,2.3$, and $2.1^{\circ} \mathrm{C}$ less, respectively, in areas of emergent marsh vegetation compared to temperatures in areas of submerged vegetation. The diurnal temperature cycle showed the greatest range in water temperatures at all three water depths in the afternoon compared to temperatures in the morning, demonstrating the effect of solar radiation. In spring, the mean temperature at 3 p.m was cooler in areas of emergent vegetation than in areas of submerged vegetation at the surface, the mid-point, and near the sediment of the water column by $3.9,3.6$, and $2.3^{\circ} \mathrm{C}$, respectively,. Also, the data showed that the water temperatures were significantly cooler, by $1.0^{\circ} \mathrm{C}$ or more, in the interior of the wetland, away from the inflow of water, in areas of both emergent and submerged vegetation, demonstrating the cumulative effect of shading from the emergent marsh vegetation on temperature over time as water moved through the wetland.

Table 5. Summary of water temperatures for sites near the inflow and sites in the wetland interior in areas of submerged vegetation and emergent vegetation, Twitchell Island, California, July 2005 through December 2006.

[All comparisons of means were significant at $\mathrm{p}<0.05$; standard error for all means was less than \pm 0.1 . Abbreviations: max, maximum; min, minimum; $\mathrm{N}$, number of samples; ${ }^{\circ} \mathrm{C}$, degree Celsius]

\begin{tabular}{|c|c|c|c|c|c|c|c|c|c|}
\hline \multirow[b]{2}{*}{$\begin{array}{l}\text { Water } \\
\text { depth }\end{array}$} & \multicolumn{4}{|c|}{ Near inflow } & \multicolumn{4}{|c|}{ Interior } & \multirow{2}{*}{$\begin{array}{c}\text { Difference }^{1} \\
\left({ }^{\circ} \mathrm{C}\right)\end{array}$} \\
\hline & $\mathbf{N}$ & $\begin{array}{c}\text { Mean } \\
\left({ }^{\circ} \mathrm{C}\right)\end{array}$ & $\begin{array}{l}\text { Min } \\
\left({ }^{\circ} \mathrm{C}\right)\end{array}$ & $\begin{array}{l}\operatorname{Max} \\
\left({ }^{\circ} \mathrm{C}\right)\end{array}$ & $\mathbf{N}$ & $\begin{array}{c}\text { Mean } \\
\left({ }^{\circ} \mathrm{C}\right)\end{array}$ & $\begin{array}{l}\text { Min } \\
\left({ }^{\circ} \mathrm{C}\right)\end{array}$ & $\begin{array}{l}\operatorname{Max} \\
\left({ }^{\circ} \mathrm{C}\right)\end{array}$ & \\
\hline Surface & 38,880 & 16.2 & 3.3 & 34.4 & 31,543 & 15.2 & 1.2 & 31.1 & 1.0 \\
\hline Mid-point & 35,526 & 15.5 & 3.7 & 25.6 & 32,565 & 14.0 & 3.7 & 26.3 & 1.5 \\
\hline Near-sediment & 37,004 & 14.8 & 4. 2 & 24.0 & 22,437 & 13.3 & 4.2 & 21.7 & 1.5 \\
\hline Surface & 43,336 & 15.1 & -0.2 & 28.3 & 42,117 & 14.0 & 1.2 & 27.5 & 1.1 \\
\hline Mid-point & 43,348 & 14.6 & 3.3 & 26.0 & 36,252 & 14.0 & 3.7 & 22.5 & 0.6 \\
\hline Near-sediment & 43,348 & 14.4 & 4.6 & 23.2 & 33,164 & 13.3 & 0.3 & 22.9 & 1.1 \\
\hline
\end{tabular}

${ }^{1}$ Water temperature of near inflow minus water temperature in the wetland interior for the means. 


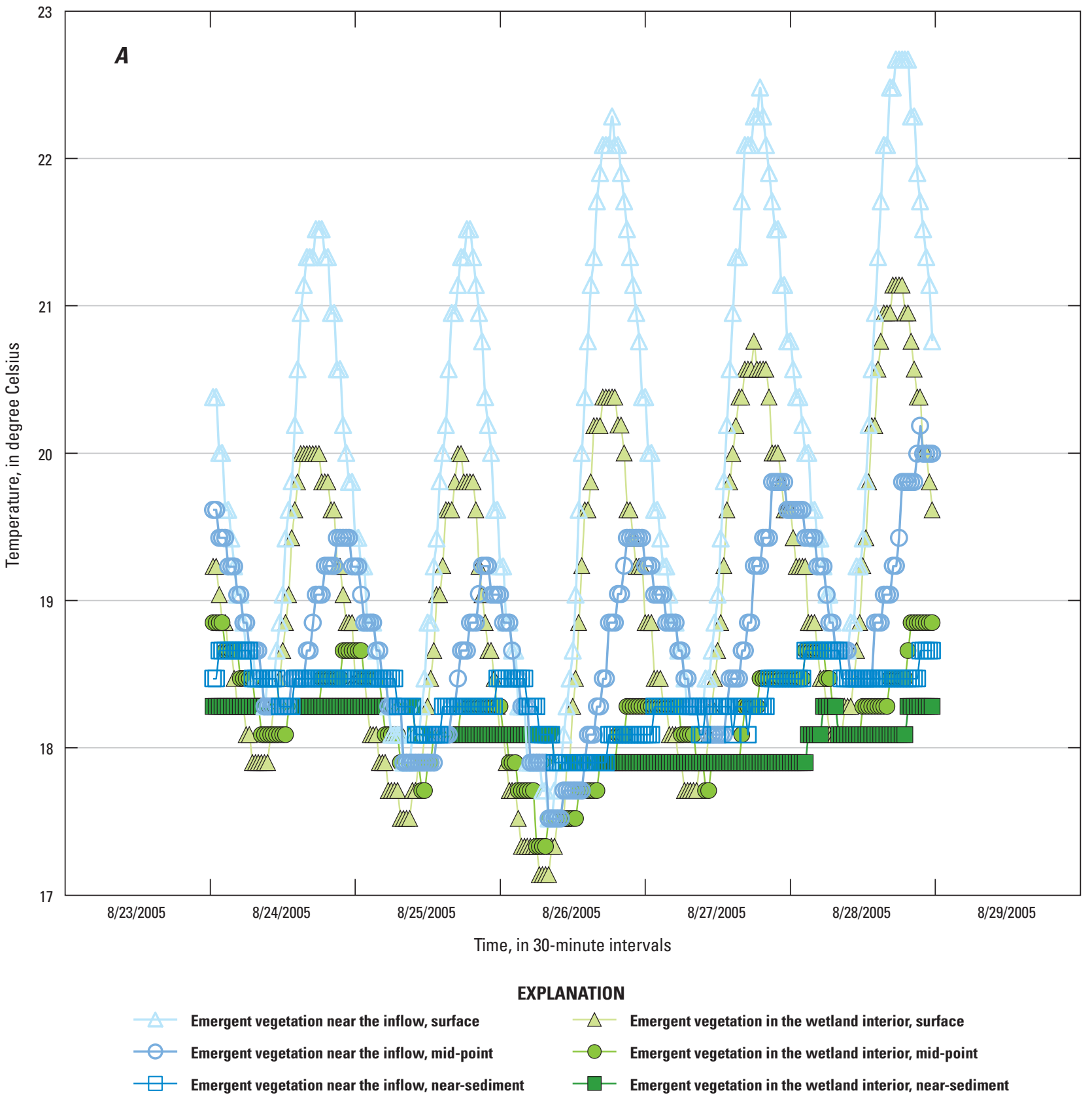

Figure 6. Water temperature recorded during August 24-28, 2005, Twitchell Island, California, for sites near the inflow compared to water temperature for sites in the interior in areas of $A$, emergent vegetation; and $B$, submerged vegetation. 


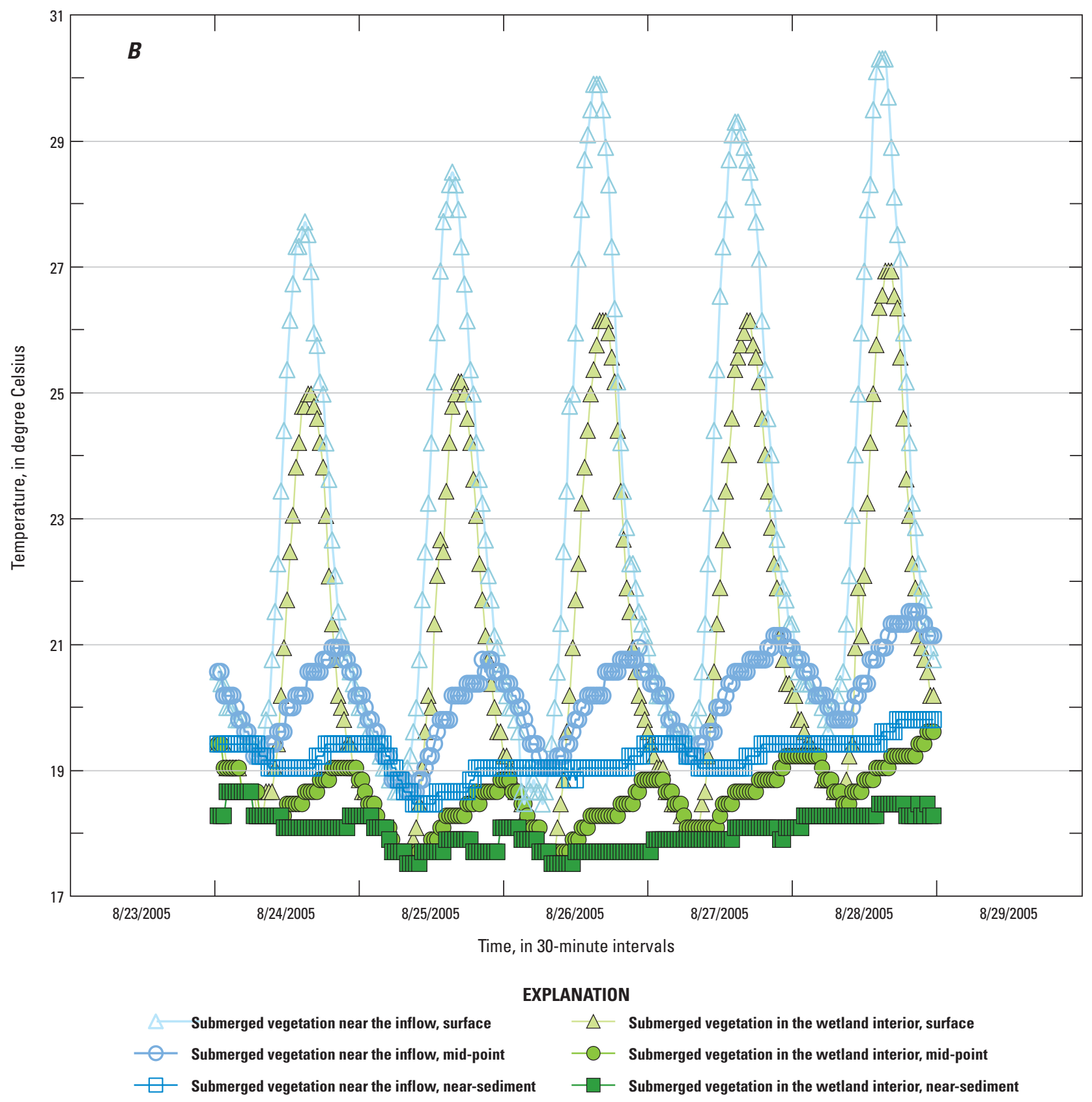

Figure 6. - Continued 


\section{References Cited}

Akratos, C.S., and Tsihrintzis, A.V., 2007, Effect of temperature, HRT, vegetation and porous media on removal efficiency of pilot-scale horizontal subsurface flow constructed wetlands: Ecological Engineering, v. 29, p. 173-191.

Bachand, P.A.M., and Horne, A.J., 2000, Denitrification in constructed free-water surface wetlands: II. Effects of vegetation and temperature: Ecological Engineering, v. 14, p. 17-32.

Deverel, S.J., and Rojstaczer S., 1996, Subsidence of agricultural lands in the Sacramento-San Joaquin Delta, California: Role of aqueous and gaseous carbon: Water Resources Research, v. 32, no. 8, p. 2359-2367.

Gamble, J.M., Burow, K.R., Wheeler, G.A., Hilditch, R., and Drexler, J.Z., 2003, Hydrogeologic data from a shallow flooding demonstration project, Twitchell Island, California, 1997-2001: U.S. Geological Survey Open-File Report 03-378, 42 p., http://pubs.usgs.gov/of/2003/ofr03378/

Kadlec, R.H., and Reddy, K.R., 2001, Temperature effects in treatment wetlands: Water Environment Research, v. 73, no.5, p. 543-557, accessed October 2010, http://www.jstor. org/stable/25045537.

Knowles, Noah, 2010, Potential inundation due to rising sea levels in the San Francisco Bay Region: San Francisco Estuary and Water Science, v. 8 no. 1, accessed October 2010, at http://www.escholarship.org/uc/item/8ck5h3qn.

Miller, R.L., 2011, Carbon gas fluxes in re-established wetlands on organic soils differ relative to plant community and hydrology: Wetlands, v. 31, no. 6, p. 1055-1066, http:// link.springer.com/article/10.1007/s13157-011-0215-2.

Miller, R.L., and Fujii, Roger, 2010, Plant community, primary productivity, and environmental conditions following wetland re-establishment in the Sacramento-San Joaquin Delta, California: Wetlands, Ecology and Management, v. 18, p. 1-16, http://link.springer.com/article/10.1007/ s11273-009-9143-9.

Miller, R.L., and Fujii, Roger, 2011, Re-establishing marshes can turn a current carbon source into a carbon sink in the Sacramento-San Joaquin Delta of California, USA, in River Deltas: Types, Structures and Ecology, ed., Contreras, D.A., New York, Nova Science Publishers, Inc., p. 1-34, https://www.novapublishers.com/catalog/product_info. php?products_id $=21836$.
Miller, R.L., Fram, M.S., Fujii, Roger, and Wheeler, Gail, 2008, Subsidence reversal in a re-established wetland in the Sacramento-San Joaquin Delta, California, USA: San Francisco Estuary and Watershed Science, v. 6, no. 3, p. 1-20, https://escholarship.org/uc/item/5j76502x.

Mitsch, W.J., and Gosselink J.G., 1993, Wetlands (2d ed.): New York, John Wiley and Sons, Inc., 722 p.

Mount, Jeffrey, and Twiss, Robert, 2005, Subsidence, sea level rise, and seismicity in the Sacramento-San Joaquin delta: San Francisco Estuary and Watershed Science, v. 3, no. 1, 18 p., http://escholarship.org/uc/item/4k44725p.

Neubauer, S.C., Givler, Kim, Valentine, SarahKeith, and Megonigal J.P., 2005, Seasonal patterns and plant-mediated controls of subsurface wetland biogeochemistry: Ecology, v. 86 , no. 12 , p. $3334-3344$.

Nolte Associates, Inc., 1999, Sacramento constructed wetlands demonstration project, five-year summary report 19941998: Sacramento Regional County Sanitation District, accessed October 2010, at http://www.regionalsan.com/pod/ sacramento-constructed-wetlands-demonstration-projectreport.

Rojstaczer, Stuart, and Deverel, S.J., 1995, Land subsidence in drained histosols and highly organic mineral soils of California: Soil Science Society of America Journal, v. 59, p. 1162-1167. 
This page intentionally left blank. 


\section{Appendix}




\section{Appendix 1.}

Water temperature data recorded every 30 minutes for all eight sites in the 55-centimeter deep wetland from July 8, 2005, to February 11, 2008, Twitchell Island, California.

(Provided separately as a downloadable Microsoft Excel ${ }^{\circledR}$ file.) 


\section{Appendix 2.}

Photosynthetically active radiation (PAR) for all eight sites in the 55-centimeter deep wetland from July 13, 2005, to November 10, 2005, Twitchell Island, California. 
Table 2-1. Photosynthethically active radiation for all eight sites in the 55-centimeter deep wetland from July 13,2005 to November 10, 2005, Twitchell Island, California.

[Abbreviations: hh:mm, hour:minute; $\mathrm{mm} / \mathrm{dd} / \mathrm{yyyy}$, month/day $/$ year; $\mu \mathrm{mol} / \mathrm{m}^{2} / \mathrm{sec}$, micromole per meter squared per second]

\begin{tabular}{|c|c|c|c|c|c|c|c|c|c|c|}
\hline \multirow{2}{*}{ Number } & \multirow{2}{*}{$\begin{array}{c}\text { Date } \\
\text { (mm/dd/yyyy) }\end{array}$} & \multirow{2}{*}{$\begin{array}{c}\text { Time } \\
\text { (hh:mm) }\end{array}$} & \multicolumn{8}{|c|}{ Photosynthetically active radiation $\left(\mu \mathrm{mol} / \mathrm{m}^{2} / \mathrm{sec}\right)$} \\
\hline & & & Site 1 & Site 5 & Site 7 & Site 8 & Site 2 & Site 3 & Site 4 & Site 6 \\
\hline 1 & $07 / 13 / 2005$ & 09:00 to $10: 00$ & 5 & 11.6 & 25 & 1,100 & 1,245 & 1,255 & 1,345 & 1,326 \\
\hline 2 & $07 / 19 / 2005$ & $09: 30$ to $10: 45$ & 7 & 16 & 13 & 80 & 1,550 & 1,420 & 1,665 & 1,630 \\
\hline 3 & $07 / 22 / 2005$ & $09: 30$ to $10: 00$ & 6 & 11 & 12 & 300 & 1,410 & 1,410 & 1,280 & 1,280 \\
\hline 6 & $08 / 16 / 2005$ & $10: 30$ to $11: 15$ & 15 & 25 & 19 & 500 & 1,475 & 1,385 & 1,670 & 1,660 \\
\hline 7 & $08 / 24 / 2005$ & $10: 30$ to $11: 15$ & 75 & 22 & 11 & 56 & 1,585 & 1,640 & 1,490 & 1,490 \\
\hline 8 & $08 / 31 / 2005$ & $10: 00$ to $11: 00$ & 250 & 17 & 13 & 50 & 1,475 & 1,480 & 1,415 & 1,430 \\
\hline 9 & $09 / 15 / 2005$ & $10: 30$ to $11: 30$ & 5 & 18 & 11 & 50 & 1,580 & 1,580 & 1,530 & 1,525 \\
\hline 10 & $09 / 30 / 2005$ & $10: 00$ to $11: 00$ & 3 & 12 & 7 & 800 & 1,200 & 1,215 & 1,100 & 1,150 \\
\hline \multirow{3}{*}{13} & & Mean & 33 & 18 & 14 & 301 & 1,446 & 1,454 & 1,414 & 1,402 \\
\hline & & Standard deviation & 68 & 6 & 5 & 374 & 237 & 198 & 267 & 291 \\
\hline & & Median & 6 & 17 & 13 & 80 & 1,475 & 1,420 & 1,430 & 1,430 \\
\hline
\end{tabular}


Prepared by the Sacramento Publishing Service Center.

For more information concerning this report, contact:

Director

U.S. Geological Survey

California Water Science Center

6000 J Street, Placer Hall

Sacramento, CA 95819

dc_ca@usgs.gov

or visit our Web site at:

http://ca.water.usgs.gov 


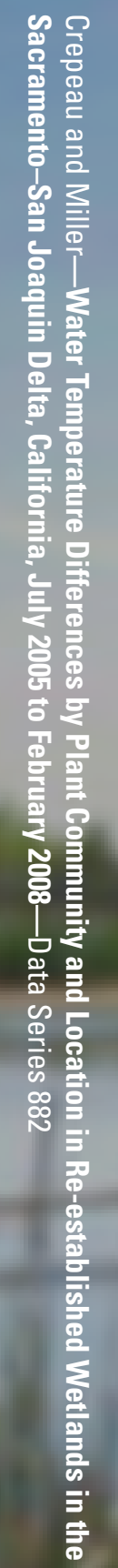

